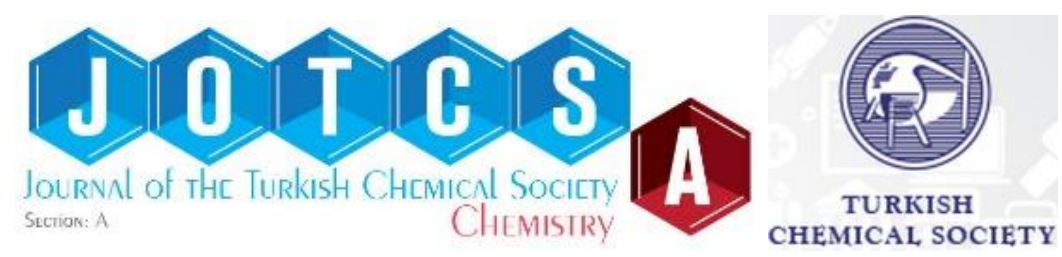

\title{
The Novel bis-dioxime-based and Boronic acid-capped Groups Containing Fe(II) and Co(II) Complexes: Synthesis, Characterization and Spectroscopy
}

(This article was initially submitted to the VI ${ }^{\text {th }}$ Inorganic Chemistry Congress in Burdur, 2017 and is now under JOTCSA's peer review).

Ahmet Kilic ${ }^{1}$, Adem Erdogan ${ }^{1}$ and Mustafa Durgun ${ }^{1,2 *}$

${ }^{1}$ Harran University, Faculty of Arts and Sciences, Department of Chemistry, 63290, Şanlıurfa TÜRKIYE

${ }^{2}$ Harran University, Faculty of Education, Department of Science Education, 63290, Şanlıurfa TÜRKiYE

\begin{abstract}
In the present work, firstly the novel monoxime (1) and asymmetric dioxime ligand $\mathbf{( \mathbf { L H } _ { 2 } )}$ (2) derived 4'-hydroxyvalerophenone as ketone was prepared under optimum reaction conditions. Then, the bis-dioxime-based and boronic acid-capped groups containing $\mathrm{Fe}$ (II) and $\mathrm{Co}$ (II) complexes $\left[(\mathbf{L})_{2} \mathbf{M}(\mathbf{X})_{2}\right.$ (BA) $\mathbf{2}_{2}$ (3-6) ( $\mathrm{L}=$ Dioxime, $\mathrm{M}=\mathrm{Fe}$ (II) or $\mathrm{Co}(\mathrm{II}), \mathrm{X}=\mathrm{Cl}_{2}$ or $\mathrm{H}_{2} \mathrm{O}$ and $\mathrm{BA}=$ Butyl boronic acid (BBA) or Ferrocene boronic acid (FBA)) were synthesized into a two-necked round-bottom flask by direct interaction of the dioxime ligand (2), and different boronic acid with metal salts $\left(\mathrm{FeCl}_{2} .4 \mathrm{H}_{2} \mathrm{O}\right.$ or $\left.\mathrm{CoCl}_{2}\right)$ without special requirement of any additional chemical process. The prepared ligands and their $\mathrm{Fe}$ (II) and Co(II) complexes were characterized by melting points, FT-IR, UV-Vis, LC-MS, NMR spectra $\left({ }^{1} \mathrm{H}\right.$ and $\left.{ }^{13} \mathrm{C}\right)$, elemental analysis, as well as magnetic susceptibility measurements. The spectroscopic results demonstrate that the proposed $\mathrm{Fe}$ (II) and $\mathrm{Co}$ (II) complexes consist of six-coordinated species and possess the octahedral geometry. The FT-IR spectra of the $\mathrm{Fe}$ (II) and $\mathrm{Co}$ (II) complexes reveal the existence of the characteristic peaks at range from 1208 to $1217 \mathrm{~cm}^{-1}$ corresponding to (B-O) stretching.
\end{abstract}

Keywords: Bis-dioximates, Fe(II) and Co(II) complexes, spectroscopy, boronic acid.

Submitted: June 1, 2017. Accepted: August 8, 2017.

Cite this: Kılıç A, Erdoğan A, Durgun M. The Novel bis-dioxime-based and Boronic acidcapped Groups Containing Fe(II) and Co(II) Complexes: Synthesis, Characterization and Spectroscopy. JOTCSA. 2017;4(sp. is. 1):11-22.

DOI: $10.18596 /$ jotcsa. 318141

*Corresponding author. E-mail: mustafadurgun@harran.edu.tr, T: +90414318 3000 $-1185$. 


\section{INTRODUCTION}

A comprehensive literature survey shows that the dioxime or vic-dioxime compounds are easy-to-handle, air-stable, distinctive structures and they have been considered as attractive raw materials for today's chemical industry and synthetic chemistry. Moreover, due to various electrochemical, spectroscopic, magnetic and catalytic properties of these compounds; different dioxime ligands and their metal complexes are of great importance in the study of molecular materials [1-4]. Besides these chemical properties, there were many reports in the literature dealing with the bis-dioxime-based and boronic acid-capped groups containing cage-type $\mathrm{Fe}$ (II) and $\mathrm{Co}(\mathrm{II})$ complexes for different purposes in modern chemistry. In recent years, the scope of vic-dioximes and their various metal complexes have been expanding among material scientists, pharmacists, chemists, biologists, physicists and so on due to their widespread potential applications.

Vic-dioximes ligands have three isomers which occur in syn (a), anti $(\beta)$, and amphi $(\gamma)$ arrangements, $[5,6]$ respectively. The nomenclature of each isomer is defined by the location of the hydroxyl groups in corresponding dioxime compounds. In order to avoid locational limitations of the hydroxyl groups, different nomenclature techniques have been used for vic-dioximes. The metal complexes of anti isomers are more stable than the metal complexes formed by amphi isomers. The syn form of isomer does not form complex with metal ions due to the steric hindrance. The planar structure of 1,2-dioximes is balanced by hydrogen bonding interactions is also considered as the reason of the recognizable steadiness and sole electronic specifications of vic-dioxime complexes [7-10].

The literature research of the related bis-dioxime-based and boronic acid-capped groups containing vic-doxime complexes shows that the dioxime ligands widely used in synthesis studies, either a known ligand or the bought from commercial suppliers and used as received. Whereas, our research group has been synthesized dioxime ligands a straightforward and rapid two-step method from various ketones as newly compounds. In this context, the monoxime, dioxime ligand, and the bis-dioxime-based and boronic acidcapped groups containing Fe(II) and Co(II) complexes were synthesised. The synthesized compounds were characterized by UV-vis, FT-IR, LC-MS, ${ }^{1} \mathrm{H}$ and ${ }^{13} \mathrm{C}-\mathrm{NMR}$ spectroscopic techniques, melting points, magnetic susceptibility measurements and elemental analysis. 


\section{EXPERIMENTAL SECTION}

\section{Materials and Measurements}

Commercially available starting materials and organic solvents were purchased from their commercial sources and used as received. For dioxime ligands, the ${ }^{1} \mathrm{H}$ and ${ }^{13} \mathrm{C}$ NMR spectra were recorded on an Agilent-VNMRS-400 NMR operating at 400 and $100 \mathrm{MHz}$, respectively. The ${ }^{1} \mathrm{H}$ NMR chemical shifts were referenced to the residual solvent as determined relative to TMS $(\delta=0 \mathrm{ppm})$ with chemical shifts given in parts per million at $25^{\circ} \mathrm{C}$. The NMR spectra of the $\mathrm{Fe}$ (II) and $\mathrm{Co}$ (II) complexes not measured because of the paramagnetic properties of complexes. Elemental analyses $(\mathrm{C}, \mathrm{H}$, and $\mathrm{N}$ ) were performed on a LECO CHNS model 932 of the elemental analyser. FT-IR spectra were collected on a Perkin-Elmer Two UATRFT spectrometer in the range of 400 to $4000 \mathrm{~cm}^{-1}$. UV-visible spectra were obtained using quartz cells at $25^{\circ} \mathrm{C}$ in a Perkin-Elmer model Lambda 25 spectrophotometer in the range of 200 to $1100 \mathrm{~nm}$ and $\mathrm{C}_{2} \mathrm{H}_{5} \mathrm{OH} / \mathrm{CH}_{2} \mathrm{Cl}_{2}$ were used as solvents. The mass spectra (LC-MS) were obtained using an Agilent LC-MS/MS spectrometer. Magnetic susceptibilities data were performed on a Sherwood Scientific Magnetic Susceptibility Balance (Model MK1) at room temperature using $\mathrm{Hg}\left[\mathrm{Co}(\mathrm{SCN})_{4}\right]$ as calibrant; diamagnetic corrections were calculated from Pascal's constants [11].

\section{Synthesis of the monoxime (1) and the dioxime ligand $\left(\mathrm{CH}_{2}\right)(2)$}

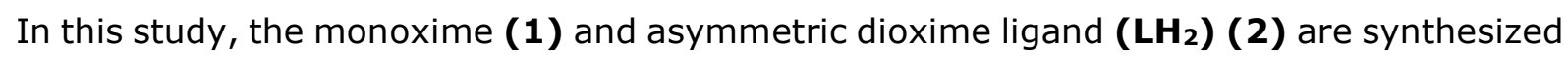
from 4 '-hydroxyvalerophenone under optimum conditions, following the similar procedure with some modifications $[12,13]$. The corresponding syntheses are briefly given in Scheme 1.

Monoxime (1): Color: pale yellow, yield: $82 \%$, mp: $98{ }^{\circ} \mathrm{C}$, Anal. Calc. for $\mathrm{C}_{11} \mathrm{H}_{13} \mathrm{NO}_{3}(\%)$ : C 63.75, H 6.32, N 6.76. Found: C 63.67, H 6.23, N 6.71. LC-MS (Scan ES ${ }^{+}$): $m / z: 207.2$ $\left(\mathrm{M}^{+}, 15\right), 190.9(25), 132.8(45), 101.2(100)$. IR $\left(\mathrm{cm}^{-1}\right): 3352$ and $3222 \mathrm{u}(\mathrm{O}-\mathrm{H}), 3057$ $\mathrm{u}(\mathrm{Ar}-\mathrm{CH}), 2960-2861 \mathrm{u}($ Aliph-CH) $1644 \mathrm{u}(\mathrm{C}=\mathrm{O}), 1605 \mathrm{u}(\mathrm{C}=\mathrm{N}), 1456-1426 \mathrm{u}(\mathrm{C}=\mathrm{C})$, and $1224 \mathrm{u}(\mathrm{N}-\mathrm{O}) .{ }^{1} \mathrm{H}$ NMR (300 MHz, DMSO-d $): \delta: 10.56$ (s, $\left.1 \mathrm{H}, \mathrm{C}=\mathrm{NOH}\right), 7.42(\mathrm{~d}, \mathrm{j} 7.0 \mathrm{~Hz}$, $2 \mathrm{H}, \operatorname{Ar}-\mathrm{H}), 6.82(\mathrm{~d}, \mathrm{~J} 7.0 \mathrm{~Hz}, 2 \mathrm{H}, \mathrm{Ar}-\mathrm{H}), 3.59(\mathrm{~s}, 1 \mathrm{H}, \mathrm{Ar}-\mathrm{OH}), 1.53-1.24\left(\mathrm{~m}, 4 \mathrm{H}, \mathrm{CH}_{3}-\mathrm{CH}_{2}-\right.$ $\left.\mathrm{CH}_{2}\right), 2.11\left(\mathrm{~s}, 3 \mathrm{H},-\mathrm{CH}_{2}-\mathrm{CH}_{3}\right) .{ }^{13} \mathrm{C} \mathrm{NMR}\left(75 \mathrm{MHz}, \mathrm{DMSO}-\mathrm{d}_{6}\right): \delta: 185.60(\mathrm{C}=\mathrm{O}), 154.82$ $(\mathrm{C}=\mathrm{NOH}), 131.7,129.0,127.5,115.6(\mathrm{Ar}-\mathrm{CH}), 28.6\left(\mathrm{CH}_{2}-\mathrm{CH}_{3}\right), 26.7,20.0\left(\mathrm{CH}_{2}-\mathrm{CH}_{2}\right)$, $14.4\left(\mathrm{CH}_{2}-\mathrm{CH}_{3}\right)$. UV $\left(\mathrm{C}_{2} \mathrm{H}_{3} \mathrm{OH}, *=\right.$ shoulder peak $) \lambda \max : 284 \mathrm{~nm}, * 293 \mathrm{~nm} ;\left(\mathrm{CH}_{2} \mathrm{Cl}_{2}\right.$, $*=$ shoulder peak) $\lambda_{\max }: 292 \mathrm{~nm}, * 301 \mathrm{~nm}$.

Dioxime ligand ( $\left.\mathbf{L H}_{2}\right)$ (2): Color: yellow, yield: $78 \%, \mathrm{mp}: 123{ }^{\circ} \mathrm{C}$, Anal. Calc. for $\mathrm{C}_{11} \mathrm{H}_{14} \mathrm{~N}_{2} \mathrm{O}_{3}(\%)$ : C 59.45, H 6.35, N 12.60. Found: C 59.38, H 6.28, N 12.51. LC-MS (Scan 
$\left.\mathrm{ES}^{+}\right): \mathrm{m} / \mathrm{z}: 223.00(\mathrm{M}+\mathrm{H}, 12), 179.0(75), 133.0$ (35), $101.0(100) . \mathrm{IR}\left(\mathrm{cm}^{-1}\right): 3343$ and $3219 \mathrm{u}(\mathrm{O}-\mathrm{H}), 3062 \mathrm{u}($ Ar-CH), 2963-2866 u(Aliph-CH), $1600 \mathrm{u}(\mathrm{C}=\mathrm{N}), 1511-1426 \mathrm{u}(\mathrm{C}=\mathrm{C})$ and $1241 \mathrm{u}(\mathrm{N}-\mathrm{O}) .{ }^{1} \mathrm{H}$ NMR (300 MHz, DMSO-d $\left.\sigma_{1}\right): \delta: 10.78(\mathrm{~s}, 1 \mathrm{H}, \mathrm{C}=\mathrm{N}-\mathrm{OH}$ ), 9.63 (br s, $1 \mathrm{H}, \mathrm{C}=\mathrm{N}-\mathrm{OH}), 7.47(\mathrm{~d}, \mathrm{~J} 7.2 \mathrm{~Hz}, 2 \mathrm{H}, \mathrm{Ar}-\mathrm{CH}), 6.78(\mathrm{~d}, \mathrm{~J} 7.2 \mathrm{~Hz}, 2 \mathrm{H}, \mathrm{Ar}-\mathrm{CH}), 3.45(\mathrm{~s}, 1 \mathrm{H}$, Ar-OH), $1.58-1.29\left(\mathrm{~m}, 4 \mathrm{H}, \mathrm{CH}_{3}-\mathrm{CH}_{2}-\mathrm{CH}_{2}\right), 0.91\left(\mathrm{t}, \mathrm{J} 3.0 \mathrm{~Hz}, 3 \mathrm{H},-\mathrm{CH}_{2}-\mathrm{CH}_{3}\right) .{ }^{13} \mathrm{C}-\mathrm{NMR}$ (75 $\left.\mathrm{MHz}, \mathrm{DMSO}-\mathrm{d}_{6}\right): \delta: 158.4,156.9(\mathrm{C}=\mathrm{NOH}), 130.8,128.8,127.5,115.6(\mathrm{Ar}-\mathrm{CH}), 28.75$ $\left(\mathrm{CH}_{2}-\mathrm{CH}_{3}\right), 26.80,22.83\left(\mathrm{CH}_{2}-\mathrm{CH}_{2}\right), 14.31\left(\mathrm{CH}_{2}-\mathrm{CH}_{3}\right)$. UV $\left(\mathrm{C}_{2} \mathrm{H}_{5} \mathrm{OH}, *=\right.$ shoulder peak $) \lambda_{\max }$ : $224 \mathrm{~nm}, 262 \mathrm{~nm},\left(\mathrm{CH}_{2} \mathrm{Cl}_{2}, *=\right.$ shoulder peak $) \lambda \max : 223 \mathrm{~nm}, 257 \mathrm{~nm}$, *329 nm.

\section{General procedures for the synthesis of $\left[\mathrm{L}_{2} \mathrm{MX}_{2}(B A)_{2}\right](3-6)$ complexes}

The Fe(II) and $\mathrm{Co}$ (II) complexes were synthesized using dioxime ligand (2), and different boronic acid with metal salts $\left(\mathrm{FeCl}_{2} .4 \mathrm{H}_{2} \mathrm{O}\right.$ or $\left.\mathrm{CoCl}_{2}\right)$. In a $100 \mathrm{~mL}$ of two-necked roundbottom flask, a solution of dioxime ligand (2) (2.0 mol) in $60 \mathrm{~mL}$ of $\mathrm{CH}_{3} \mathrm{NO}_{2}$ was stirred at $25{ }^{\circ} \mathrm{C}$ under argon atmosphere for $15 \mathrm{~min}$. to completely dissolve the dioxime ligand. Then, appropriate $\mathrm{FeCl}_{2} .4 \mathrm{H}_{2} \mathrm{O}$ or $\mathrm{CoCl}_{2}$ salt $(1.0 \mathrm{~mol})$ was added to the reaction flask in small portions. Following to this step, butyl boronic acid (BBA) or ferrocene boronic acid (FBA) $(2.0 \mathrm{~mol})$ was added and the mixture was stirred under reflux for $8 \mathrm{~h}$. After cooling to 25 ${ }^{\circ} \mathrm{C}$, the solvent was evaporated to approximately half the original volume and the remaining solution was kept overnight, during which a dark orange or dark brown precipitate appeared. The precipitate was then collected, washed with diethyl ether, nhexane, and cold ethanol and dried in vacuo. Finally, the corresponding metal complexes were recrystallized from $\mathrm{CH}_{2} \mathrm{Cl}_{2} / \mathrm{n}$-hexane mixture.

[( ()$_{2} \mathbf{F e}(\mathrm{Cl})_{2}(\boldsymbol{B B A})_{2}$ ] (3): Color: brown, yield: $62 \%, \mathrm{mp}:>300{ }^{\circ} \mathrm{C}$, Anal. Calc. for $\mathrm{C}_{30} \mathrm{H}_{42} \mathrm{~N}_{4} \mathrm{O}_{6} \mathrm{~B}_{2} \mathrm{FeCl}_{2}(\%)$ : C 51.25, H 6.02, N 7.97. Found: C 51.18, H 6.04, N 7.91. LC-MS $\left(\right.$ Scan ES $\left.{ }^{+}\right): m / z: 703.3\left(\mathrm{M}^{+}, 25\right), 627.8(35), 412.9$ (55), 217.8 (100). Heff: 4.85 B.M. $\Lambda_{m}$ : $12.6\left(\Omega^{-1} \mathrm{~cm}^{2} \mathrm{~mol}^{-1}\right)$. IR $\left(\mathrm{cm}^{-1}\right): 3320 \mathrm{u}(\mathrm{O}-\mathrm{H}), 3059 \mathrm{u}(\mathrm{Ar}-\mathrm{CH}), 2957-2872 \mathrm{u}($ Aliph-CH), $1649 \mathrm{u}(\mathrm{C}=\mathrm{N}), 1506-1412 \mathrm{u}(\mathrm{C}=\mathrm{C}), 1260 \mathrm{u}(\mathrm{N}-\mathrm{O})$ and $1217 \mathrm{u}(\mathrm{B}-\mathrm{O})$. UV $\left(\mathrm{C}_{2} \mathrm{H}_{5} \mathrm{OH}, *=\right.$ shoulder peak) $\lambda$ max: $221 \mathrm{~nm}, * 274 \mathrm{~nm},\left(\mathrm{CH}_{2} \mathrm{Cl}_{2}, *=\right.$ shoulder peak $) \lambda_{\max }: 266 \mathrm{~nm}, 286$ $\mathrm{nm}, 294 \mathrm{~nm}, * 327 \mathrm{~nm}$.

[( ()$_{3} \mathbf{C o}\left(\mathrm{H}_{2} \mathrm{O}\right)_{2}(\boldsymbol{B B A})_{2}$ ] (4): Color: Dark brown, yield: $65 \%$, mp: $>300{ }^{\circ} \mathrm{C}$, Anal. Calc. for $\mathrm{C}_{30} \mathrm{H}_{46} \mathrm{~N}_{4} \mathrm{O}_{8} \mathrm{~B}_{2} \mathrm{Co}$ (\%): C 53.68, H 6.91, N 8.35. Found: C 53.63, H 6.88, N 8.28. LC-MS

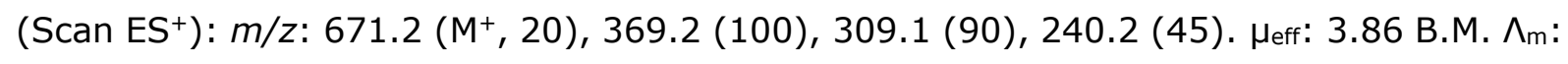
$15.0\left(\Omega^{-1} \mathrm{~cm}^{2} \mathrm{~mol}^{-1}\right)$. IR $\left(\mathrm{cm}^{-1}\right): 3324 \mathrm{v}(\mathrm{O}-\mathrm{H}), 3053 \mathrm{u}(\mathrm{Ar}-\mathrm{CH}), 2962-2869 \mathrm{u}($ Aliph-CH), $1651 \mathrm{u}(\mathrm{C}=\mathrm{N}), 1509-1410 \mathrm{u}(\mathrm{C}=\mathrm{C}), 1266 \mathrm{u}(\mathrm{N}-\mathrm{O})$ and $1219 \mathrm{u}(\mathrm{B}-\mathrm{O}) . \mathrm{UV}\left(\mathrm{C}_{2} \mathrm{H}_{5} \mathrm{OH} *=\right.$ shoulder peak) $\lambda$ max: $226 \mathrm{~nm}, 256 \mathrm{~nm}, * 404 \mathrm{~nm},\left(\mathrm{CH}_{2} \mathrm{Cl}_{2} *=\right.$ shoulder peak) $\lambda$ max: $269 \mathrm{~nm}, 285$ $\mathrm{nm}, 297 \mathrm{~nm}, * 386 \mathrm{~nm}$. 
[( ()$\left._{2} \mathbf{F e}(\mathrm{Cl})_{2}(F B A)_{2}\right]$ (5): Color: brown, yield: 69\%, m.p: $>300{ }^{\circ} \mathrm{C}$, Anal. Calc. for $\mathrm{C}_{42} \mathrm{H}_{44} \mathrm{~N}_{4} \mathrm{O}_{6} \mathrm{~B}_{2} \mathrm{Fe}_{3} \mathrm{Cl}_{2}$ (\%): C 52.50, H 4.62, N 5.83. Found: C 52.46, H 4.58, N 5.80. LC-MS $\left(\right.$ Scan ES $\left.{ }^{+}\right): m / z: 960.8\left(\mathrm{M}^{+}, 45\right), 765.5$ (15), 526.7 (18), 146.7 (15). $\mu_{\text {eff: }} 4.94$ B.M. $\Lambda_{m}$ : $16.1\left(\Omega^{-1} \mathrm{~cm}^{2} \mathrm{~mol}^{-1}\right)$. IR $\left(\mathrm{cm}^{-1}\right): 3332 \mathrm{v}(\mathrm{O}-\mathrm{H}), 3064 \mathrm{v}(\mathrm{Ar}-\mathrm{CH}), 2954-2865 \mathrm{u}($ Aliph-CH), $1652 \mathrm{u}(\mathrm{C}=\mathrm{N}), 1506-1432 \mathrm{u}(\mathrm{C}=\mathrm{C}), 1261 \mathrm{u}(\mathrm{N}-\mathrm{O})$ and $1211 \mathrm{u}(\mathrm{B}-\mathrm{O})$. UV $\left(\mathrm{C}_{2} \mathrm{H}_{5} \mathrm{OH} *=\right.$ shoulder peak) $\lambda$ max: $218 \mathrm{~nm}, 270 \mathrm{~nm}, * 281 \mathrm{~nm}, 386 \mathrm{~nm},\left(\mathrm{CH}_{2} \mathrm{Cl}_{2} *=\right.$ shoulder peak $) \lambda \max : 222$ $\mathrm{nm}, 264 \mathrm{~nm}, * 329 \mathrm{~nm}$.

[( ()$_{2} \mathbf{C o}\left(\mathrm{H}_{2} \mathrm{O}\right)_{2}(\boldsymbol{F B A})_{2}$ ] (6): Color: Dark brown, yield: $66 \%$, m.p: $>300{ }^{\circ} \mathrm{C}$, Anal. Calc. for $\mathrm{C}_{42} \mathrm{H}_{48} \mathrm{~N}_{4} \mathrm{O}_{8} \mathrm{~B}_{2} \mathrm{Fe}_{2} \mathrm{Co}$ (\%): C 54.30, H 5.21, N 6.03. Found: C 54.28, H 5.23, N 6.29. LCMS (Scan ES $\left.{ }^{+}\right): m / z: 929.2\left(M^{+}, 25\right), 572.3$ (100), 463.0 (20), 218.3 (5). Heff: 3.84 B.M. $\Lambda_{\mathrm{m}} 18.4\left(\Omega^{-1} \mathrm{~cm}^{2} \mathrm{~mol}^{-1}\right)$. IR ( $\left.\mathrm{cm}^{-1}\right): 3326 \mathrm{u}(\mathrm{O}-\mathrm{H}), 3062 \mathrm{u}(\mathrm{Ar}-\mathrm{CH}), 2954-2872 \mathrm{u}($ Aliph-CH), $1653 \mathrm{u}(\mathrm{C}=\mathrm{N}), 1509-1434 \mathrm{u}(\mathrm{C}=\mathrm{C}), 1260 \mathrm{u}(\mathrm{N}-\mathrm{O})$ and $1208 \mathrm{u}(\mathrm{B}-\mathrm{O})$. UV $\left(\mathrm{C}_{2} \mathrm{H}_{5} \mathrm{OH} *=\right.$ shoulder peak) $\lambda$ max: $220 \mathrm{~nm}, 271 \mathrm{~nm}, * 368 \mathrm{~nm},\left(\mathrm{CH}_{2} \mathrm{Cl}_{2} *=\right.$ shoulder peak) $\lambda$ max: $225 \mathrm{~nm}, 260$ $\mathrm{nm}, * 324 \mathrm{~nm}, 374 \mathrm{~nm}$.

\section{RESULTS AND DISCUSSION}

\section{Synthesis}

A summary of our synthetic route for ligands and their boron-capped $\mathrm{Fe}(\mathrm{II})$ and $\mathrm{Co}$ (II) complexes are given in Scheme 1 and 2, respectively. The synthesis of the monoxime (1) were carried out in the presence of $\mathrm{C}_{2} \mathrm{H}_{5} \mathrm{ONa}$ and $\mathrm{n}$-butyl nitrite $\left(\mathrm{C}_{4} \mathrm{H}_{9} \mathrm{NO}_{2}\right)$ at $-8{ }^{\circ} \mathrm{C}$ and gave the corresponding monoxime derivative, as pale-yellow solid, in moderate to good yield (82\%) (Scheme 1). After the characterization of monoxime (1), the reaction of monoxime (1) with hydroxylamine hydrochloride $\left(\mathrm{NH}_{2} \mathrm{OH} . \mathrm{HCl}\right)$ in the presence of sodium acetate $\left(\mathrm{CH}_{3} \mathrm{COONa}\right)$ and ethanol (as the solvent) were conducted under reflux. This synthetic procedure favoured the formation of the dioxime ligands as yellow crystals (2) (Scheme 1). The progress of the reactions were systematically monitored by Thin-Layer Chromatography (TLC). Then, the expected boron-capped Fe(II) and Co(II) complexes (36) have been synthesized via $\mathrm{FeCl}_{2} .4 \mathrm{H}_{2} \mathrm{O}$ or $\mathrm{CoCl}_{2}$ salts and two equivalents of butyl boronic acid (BBA) or ferrocene boronic acid (FBA) with three equivalents of functionalized dioxime ligand (2) in $\mathrm{CH}_{3} \mathrm{NO}_{2}$ under reflux. Finally, we concluded that the synthesized ligands and their $\mathrm{Fe}$ (II) and $\mathrm{Co}$ (II) complexes optained the desired structures with enough purity for the spectroscopic methods, melting point, magnetic susceptibility measurements, and elemental analysis. The found and the calculated percentages of $\mathrm{C}, \mathrm{H}$ and $\mathrm{N}$ results agree with each other, and these prove the proposed molecular formulas. All compounds are 
soluble in common organic solvents and stable at room temperature and normal pressure, and not sensitive to light.<smiles>CCCCC(=O)c1ccc(O)cc1</smiles>

4'-hydroxyvalerophenone<smiles>CCC/C(=N\O)C(=O)c1ccc(O)cc1</smiles>

monoxime (1)<smiles>CCC/C(=N\O)C(=NO)c1ccc(O)cc1</smiles>

dioxime ligand $\left(\mathrm{LH}_{2}\right)(2)$

Scheme 1. Synthesis of the proposed monoxime (1) and dioxime ligand $\left(\mathrm{LH}_{2}\right)(\mathbf{2})$; (a): n- $\mathrm{C}_{4} \mathrm{H}_{9} \mathrm{ONO} / \mathrm{C}_{2} \mathrm{H}_{5} \mathrm{ONa},-5{ }^{\circ} \mathrm{C}$, (b): $\mathrm{CH}_{3} \mathrm{COONa} / \mathrm{NH}_{2} \mathrm{OH}$. $\mathrm{HCl} / \mathrm{EtOH}$, reflux temperature.<smiles>CCC/C(=N/O)C(=NO)c1ccc(O)cc1</smiles>

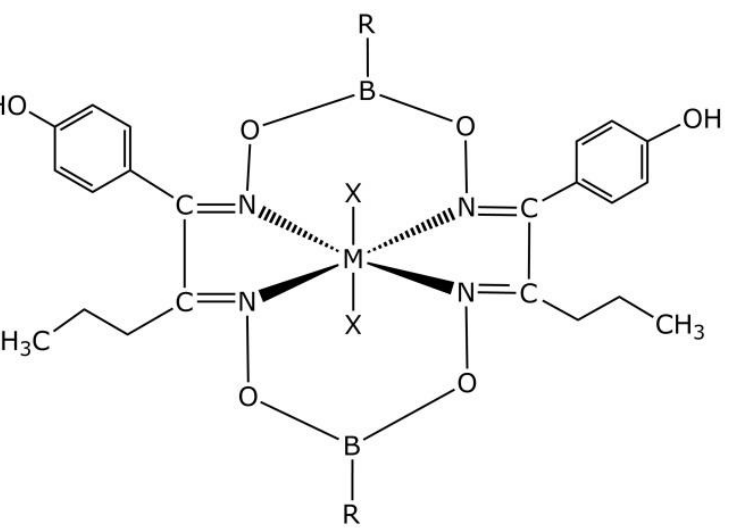

$\mathbf{M}=\mathrm{Fe}(\mathrm{II}), \mathrm{X}=\mathrm{Cl}$ or $\mathrm{Co}(\mathrm{II}), \mathrm{X}=\mathrm{H}_{2} \mathrm{O}$

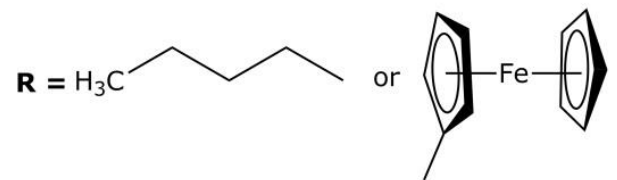

Scheme 2. The structure of the proposed the boron-capped Fe(II) and Co(II) complexes (3-6).

\section{FT-IR Spectra}

To have information about all compounds, FT-IR spectra of monoxime (1) and asymmetric dioxime ligand $\left.\mathbf{(} \mathbf{L H}_{\mathbf{2}}\right) \mathbf{~ ( 2 )}$ with the boron-capped $\mathrm{Fe}(\mathrm{II})$ and $\mathrm{Co}$ (II) complexes (3-6) were evaluated in detail. In the FT-IR spectra of monoxime (1), compared to the dioxime ligand (2), the very strong stretching vibration of the $(C=0)$ group at observed $1644 \mathrm{~cm}^{-1}$ is converted to the second $(-\mathrm{C}=\mathrm{N}-\mathrm{OH})$ group after the formed dioxime ligand from monoxime (1). However, when the FT-IR spectra of the dioxime ligand (2) were compared with that of the free monoxime (1), a small frequency shift is exhibited which may be attributed to the formation of dioxime ligand (Figure S1). The FT-IR data on the proposed chemical structure of the boron-capped $\mathrm{Fe}$ (II) and $\mathrm{Co}(\mathrm{II})$ complexes (3-6) with asymmetric dioxime 
ligand (2) can be achieved by comparing to the FT-IR spectra of the free dioxime ligand with its $\mathrm{Fe}$ (II) and $\mathrm{Co}$ (II) complexes. The main spectral variations of the $\mathrm{Fe}$ (II) and $\mathrm{Co}$ (II) complexes, compared to the free dioxime ligand (2), are found the presence of a new band at range $1208-1219 \mathrm{~cm}^{-1}$ have been assigned to the stretching vibrations of the (B-O) groups [14]. This idea is supported by the disappearance of the dioxime ligand $u(O H)$ peaks at around $3219 \mathrm{~cm}^{-1}$, which provides clear evidence occurrence of the boron-capped $\mathrm{Fe}$ (II) and $\mathrm{Co}$ (II) complexes (3-6). Another important observation for the boron-capped bis-dioximate $\mathrm{Fe}(\mathrm{II})$ and $\mathrm{Co}(\mathrm{II})$ complexes, the characteristic bands of the $\mathrm{C}=\mathrm{N}$, and $\mathrm{N}-\mathrm{O}$ stretching vibrations have shifted almost between $53 \mathrm{~cm}^{-1}$ and $25 \mathrm{~cm}^{-1}$ to higher wave numbers upon coordination. This small shift exhibits the coordination of the dioxime ligands through their imine nitrogen atoms to the Fe(II) or Co(II) metal centers. Furthermore, the other stretching vibrations in the FT-IR spectra of all compounds support the formation of the desired compounds.

\section{NMR Spectra}

The ${ }^{1} \mathrm{H}$ and ${ }^{13} \mathrm{C}$ NMR spectra of the monoxime (1) and dioxime ligand (2) were recorded in DMSO- $d_{6}$ taking TMS as an internal standard. Further evidence for the formation of the monoxime (1) and dioxime ligand (2) were obtained from the ${ }^{1} \mathrm{H}$ and ${ }^{13} \mathrm{C}$ NMR spectra. The ${ }^{1} \mathrm{H}$ and ${ }^{13} \mathrm{C}$ NMR spectra of the monoxime (1) and dioxime ligand (2) were in good agreement with the target molecules. Detailed assignments of ${ }^{1} \mathrm{H}$ and ${ }^{13} \mathrm{C} N M R$ spectra along with coupling constants of the compounds have been presented in the experimental section. Due to the paramagnetic nature of the boron-capped bis-dioximate Fe(II) and $\mathrm{Co}$ (II) complexes, the NMR analysis could not be performed. The ${ }^{1} \mathrm{H}$ and ${ }^{13} \mathrm{C}$-NMR spectra of dioxime ligand (2) depicted in Figure S2 and S3. It can be clearly seen that the appearance of the new proton and carbon signals assigned to the hydroxyl group of the oximes which is formed by the replacement of the carbonyl group by oxime moiety in monoxime (1), as expected. This new deuterium-exchangeable proton and carbon peaks of the $(\mathrm{C}=\mathrm{N}-\mathrm{O} \underline{\mathrm{H}})$ group of the dioxime ligands (2) are detected at 9.63 and $158.36 \mathrm{ppm}$ in ${ }^{1} \mathrm{H}$ and ${ }^{13} \mathrm{C}$-NMR spectra, respectively. Moreover, the absence of carbon peaks of the $(\mathrm{C}=\mathrm{O})$ group (185.60 ppm) in ${ }^{13} \mathrm{C}-\mathrm{NMR}$ spectra for the dioxime ligands (2), indicating the formation of the dioxime ligand from monoxime. Another relevant argument that confirms the formation is the presence of a new displayed peak at $3.59 \mathrm{ppm}$ for monoxime (1) and at $3.45 \mathrm{ppm}$ for the dioxime ligand (2) as singlet signals belonging to the ortho $\mathrm{O} \underline{H}$ protons of a phenyl group, respectively. Furthermore, the other displayed proton and carbon peaks in the NMR spectra of the oxime ligands (1) and (2) also support the formation of the desired compounds. 


\section{UV-Vis Spectra}

In order to obtain further structural information, the electronic spectra of the monoxime (1) and dioxime ligand (2) with their boron-capped $\mathrm{Fe}$ (II) and $\mathrm{Co}$ (II) complexes (3-6) have been measured. The electronic spectra of the monoxime (1) with dioxime ligand (2) and the boron-capped bis-dioximate $\mathrm{Fe}$ (II) and $\mathrm{Co}$ (II) complexes (3-6) were analyzed in $\mathrm{C}_{2} \mathrm{H}_{3} \mathrm{OH}$ and $\mathrm{CH}_{2} \mathrm{Cl}_{2}$ as solvents at room temperature, and the experimental techniques used to obtain the data is given in Figure S4 and Figure S5. In order to compare the UVVis spectra of the studied compounds, we have also investigated the electronic spectra of the $\mathrm{Fe}(\mathrm{II})$ and $\mathrm{Co}(\mathrm{II})$ complexes (3-6) along with that of dioxime ligand (2) under the similar experimental conditions. For the Fe(II) and $\mathrm{Co}$ (II) complexes, the characteristic spin-forbidden $d$ - $d$ transition of metal centers have not been observed in the visible region, most probably due to their very low molar absorption coefficient. However, when the UVVis results of the boron-capped bis-dioximate Fe(II) and Co(II) complexes were compared with that of the free dioxime (2) ligand, the ligand-to-metal charge transfer [LMCT, $(\mathrm{L}) \rightarrow \mathrm{Fe}(\mathrm{II})$ or $\mathrm{Co}(\mathrm{II})$ ] or metal-to-ligand charge transfer [MLCT, $\mathrm{Fe}(\mathrm{II})$ or $\mathrm{Co}(\mathrm{II}) \rightarrow(\mathrm{L})$ ] absorption bands was observed at range 368-404 nm, and these transitions which are clearly distincitve than other transitions might be attributed to the formation of metal complexes [14-16]. The capped boron groups and various metal centers might play a role in the spectral variations of ligand-to-metal charge transfer within the the $\mathrm{Fe}$ (II) and $\mathrm{Co}$ (II) complexes due to the same ligand in structures. Besides, The UV-Vis spectrum of the monoxime (1) and dioxime ligand (2) shows two or three absorption bands in the region 223-329 nm in $\mathrm{C}_{2} \mathrm{H}_{5} \mathrm{OH}$ or $\mathrm{CH}_{2} \mathrm{Cl}_{2}$ solvents, corresponding to the $\Pi \rightarrow \Pi^{*}$ or $\mathrm{n} \rightarrow \Pi^{*}$ transitions due to the $(\mathrm{C}=\mathrm{N}-\mathrm{OH})$ oxime chromophore [17]. The reason of similarity in the shapes of UV-Vis absorption bands the dioxime ligand (2) and the boron-capped bisdioximate $\mathrm{Fe}$ (II) and $\mathrm{Co}$ (II) complexes depends on the electron-withdrawing or electronreleasing group at different positions in the synthesised ligand and complexes. For Fe(II) and $\mathrm{Co}$ (II) complexes, these electronic spectra are observed at range 218-329 nm.

\section{LC-MS Spectra}

The LC-MS spectrum of the monoxime (1) and dioxime ligand (2) and their boron-capped bis-dioximate $\mathrm{Fe}$ (II) and $\mathrm{Co}$ (II) complexes (3-6) displays the principal fragment ions and the isotopic distributions of different intensities confirming their molecular weights (Figures S6-S10). The LC-MS spectra of the monoxime (1) and dioxime ligand (2) showed peaks attributed to the molecular ions $\mathrm{m} / \mathrm{z}$ at 207.20 and 223.00 , respectively. Whereas, the molecular ion peaks of the $\mathrm{Fe}(\mathrm{II})$ and $\mathrm{Co}(\mathrm{II})$ complexes (3-6) were displayed at $\mathrm{m} / \mathrm{z}=$ 703.3 for $\left[(\mathrm{L})_{2} \mathrm{Fe}(\mathrm{Cl})_{2}(\mathrm{BBA})_{2}\right]$ (3) complex, at $\mathrm{m} / \mathrm{z}=671.2$ for $\left[(\mathrm{L})_{2} \mathrm{Co}\left(\mathrm{H}_{2} \mathrm{O}\right)_{2}(\mathrm{BBA})_{2}\right]$ (4) complex, at $\mathrm{m} / \mathrm{z}=960.8$ for $\left[(\mathrm{L})_{2} \mathrm{Fe}(\mathrm{Cl})_{2}(\mathrm{FBA})_{2}\right]$ (5) complex, and at $\mathrm{m} / \mathrm{z}=929.2$ for 
$\left[(\mathrm{L})_{2} \mathrm{Co}\left(\mathrm{H}_{2} \mathrm{O}\right)_{2}(\mathrm{FBA})_{2}\right](\mathbf{6})$ complex, respectively. These mass spectra results are in good agreement with the calculated molecular weights of the target compounds.

\section{Magnetic and Molar Conductivity Studies}

The magnetic moments of the boron-capped bis-dioximate $\mathrm{Fe}$ (II) and $\mathrm{Co}$ (II) complexes (3-6) were measured at ambient temperature as B.M where $\mathrm{Hg}\left[\mathrm{Co}(\mathrm{SCN})_{4}\right]$ was used a calibrant. The metal complexes were found in paramagnetic character. The magnetic moment values for $\mathrm{Fe}$ (II) complexes found to be in the range of 4.85-4.96 B.M and this values is slightly different from the theoretical $\mu_{\text {eff }}=4.90 \mathrm{~B} . \mathrm{M}$ for a high spin $\mathrm{Fe}^{2+}$ ion. The observed values in our case were very close to the high spin-only values for four unpaired electrons, and confirm the iron in +2 oxidation state with $d^{6}$ configuration and also octahedral geometry with $\mathrm{sp}^{3} \mathrm{~d}^{2}$ hybridization. The magnetic moment values of $\mathrm{Co}$ (II) complexes found to be in range of 3.84-4.86 B.M and this values is slightly different from theoretical $\mu_{\text {eff }}=3.87 \mathrm{~B} . \mathrm{M}$ for a high spin $\mathrm{Co}^{2+}$ ion which very close to the spin-only values for three unpaired electron, and confirm the cobalt in +2 oxidation state with $d^{7}$ configuration and also octahedral geometry and $\mathrm{sp}^{3} \mathrm{~d}^{2}$ hybridization.

The molar conductivity values of the cage-type $\mathrm{Fe}(\mathrm{II})$ and $\mathrm{Co}$ (II) complexes (3-6) have been calculated in DMF at room temperature and are found in the range $12.6-18.4 \Omega^{-1} \mathrm{~cm}^{2}$ $\mathrm{mol}^{-1}$ which shows the non-electrolytic nature of the metal complexes.

\section{CONCLUSIONS}

Firstly, we have reported here the synthesis of the monoxime (1) and dioxime ligand (2) from 4 '-hydroxyvalerophenone as ketone under ambient conditions. Then, from the reactions between $\mathrm{FeCl}_{2} .4 \mathrm{H}_{2} \mathrm{O}$ or $\mathrm{CoCl}_{2}$ and dioxime ligand (2) in the mixture of $\mathrm{CH}_{3} \mathrm{NO}_{2}$ and various boronic acid, four $\mathrm{Fe}$ (II) and $\mathrm{Co}$ (II) complexes were obtained. The NMR spectra $\left({ }^{1} \mathrm{H}\right.$ and ${ }^{13} \mathrm{C}$ for monoxime (1) and dioxime ligand (2)), FT-IR spectra, UV-Vis spectra, LCMS, elemental analysis, melting point, and magnetic susceptibility measurements were used for characterization of ligand and their boron-capped Fe(II) and $\mathrm{Co}$ (II) complexes. The spectroscopic results showed that the $\mathrm{Fe}(\mathrm{II})$ and $\mathrm{Co}(\mathrm{II})$ complexes have sixcoordinated species and octahedral geometry.

\section{ACKNOWLEDGMENTS}

This study was supported by the Department of Chemistry Harran University, Sanliurfa, Turkey. 


\section{REFERENCES}

1. Whyte AM, Roach B, Henderson DK, Tasker PA, Matsushita MM, Awaga K, Robertson N. Structural, magnetic, and electronic properties of phenolic oxime complexes of $\mathrm{Cu}$ and $\mathrm{Ni}$. Inorganic chemistry. 2011 Dec; 50(24):12867-76. DOI: 10.1021/ic2020644.

2. Kelley P, Day MW, Agapie T. Hydrogen Evolution Catalyzed by Aluminum-Bridged Cobalt Diglyoximate Complexes. Inorg. Che. 2013 Aug; 2013(22-23:)3840-45. DOI: 10.1002/ejic.201300309.

3. Kilic $A$, Tas $E$, Yilmaz I. Synthesis, spectroscopic and redox properties of the mononuclear $\mathrm{Ni}^{\mathrm{II}}$, $\mathrm{Ni}^{\mathrm{II}}\left(\mathrm{BPh}_{2}\right)_{2}$ containing $(\mathrm{B}-\mathrm{C})$ bond and trinuclear $\mathrm{Cu}^{\mathrm{II}}-\mathrm{Ni}^{\mathrm{II}}-\mathrm{Cu}^{\mathrm{II}}$ type-metal complexes of $N_{1} N^{\prime}-(4-$ amino-1-benzyl piperidine)-glyoxime J. Chem. Sci. 2009 Jan; 121(1): 43-56. http://www.ias.ac.in/article/fulltext/jcsc/121/01/0043-0056.

4. Kilic A, Yilmaz I, Ulusoy M, Tas E. Synthesis, spectral characterization, electrochemical studies and catalytic properties in Suzuki-Miyaura coupling reactions of the mononuclear Pdi , trinuclear $\mathrm{Pd}^{\mathrm{II}}\left(\mathrm{BPh}_{2}\right)_{2}$ and $\mathrm{Ru}^{\mathrm{II}}=\mathrm{Pd}^{\mathrm{II}}=\mathrm{Ru}^{\mathrm{II}}$ type complexes containing 4-amino-1-benzyl piperidine and phenyl groups. Applied Organometallic Chemistry. 2008 Sep; 22(9): 494-502. DOI: $10.1002 /$ aoc. 1430.

5. Al-Obaidi FN, Atabey H, Macit M, Sari H. Potentiometric and Theoretical Studies of $(2 Z, 3 Z)-2 H-$ benzo[ $b][1,4]$ thiazine-2,3(4H)-dionedioxime with Some Divalent Transition Metal Ions. Journal of Solution Chemistry. 2014 May; 43(5):989-999. DOI: 10.1007/s10953-014-0176-1

6. Nakamura A, Konishi A, Ostuka S. Chiral metal complexes. Part 5. Cobalt(II) and some other transition-metal complexes of chiral vic-dioximate ligands derived from D-camphor and L- $\beta$-pinene. Dalton Transactions. 1979; 3: 488-495. DOI: 10.1039/DT9790000488.

7. Babahan I, Ozmen A, Orhan N, Kazar D, Degirmenci EH. Synthesis, characterization, and in vitro anti-neoplastic activity of novel vic-dioximes bearing thiosemicarbazone side groups and their mononuclear complexes. Bioorganic Chemistry. 2014 Apr; 53:92-98. DOI: 10.1016/j.bioorg.2014.01.003.

8. Mitchell P. Keilin's Respiratory Chain Concept and Its Chemiosmotic Consequences. Science. 1979 Dec; 206:1148-59.Science1979,206, 1148-1159. http://www.jstor.org/stable/1749145.

9. Cervara B, Ruiz R, Lloret F, Julve M, Faus J, Munoz MC, Journnaux Y. Interaction between heterobinuclear molecules and nature of the ground spin state in oximato-bridged $\left[\mathrm{Cu}^{\mathrm{II}} \mathrm{M}^{\mathrm{II}}\right]_{2}$ bisbinuclear complexes $(\mathrm{M}=\mathrm{Cu}, \mathrm{Ni}, \mathrm{Mn})$ : crystal structure of $\left[\mathrm{Cu}(\mathrm{pdmg}) \mathrm{Ni}\left(\mathrm{Me}_{3}[12] \mathrm{N}_{3}\right)(\mathrm{EtOH})\right]\left(\mathrm{ClO}_{4}\right)_{2}$. Inorganica Chimica Acta. 1999 May; 288(1): 57-68. DOI: 10.1016/S0020-1693(99)00035-3. 
10. Herron N, Busch DH. Reversible Dioxygen Binding by a Totally Synthetic Non-Porphyrin Macrobicyclic Iron(I1) Complex Containing a Persistent Void. Journal of the American Chemical Society. 1981 Nov; 103(5):1236-37. DOI:10.1021/ja00395a050.

11.Earnshaw A, editor. Introduction to Magnetochemistry:Chapter 1. London: Academic Press; 1968. 126 p. ISBN: 9781322266435.

12. Kilic A, Tas E, Gumgum B, Yilmaz I. Synthesis, spectral characterization and electrochemical properties of new vic-dioxime complexes bearing carboxylate. Transition Metal Chemistry.2006 Aug;31(5):645-652. DOI: 10.1007/s11243-006-0043-z.

13. Kilic A, Kilic MV, Ulusoy M, Durgun M, Aytar E, Dagdevren M, Yilmaz I. Ketone synthesized cobaloxime/organocobaloxime catalysts for cyclic carbonate synthesis from $\mathrm{CO} 2$ and epoxides: Characterization and electrochemistry. 2014 Sep;767 (2014):150-159. DOI: 10.1016/j.jorganchem.2014.05.023.

14.Artyushin OI, Matveeva EV, Vologzhanina AV, Voloshin YZ. Clathrochelates meet phosphorus. New thio-and phosphorylation reactions of an iron (II) dichloroclathrochelate precursor and preparation of its first phosphorus (III)-containing macrobicyclic derivative. Dalton Transactions. 2016 Feb;45(12): 5328-5333. DOI:10.1039/C6DT00164E.

15. Gupta BD, Qanungo K. Pyrazine bridged organodicobaloximes: a convenient one pot synthesis and cis influence studies. Journal of Organometallic Chemistry. 1998 Apr;557(2): 243-249. DOI: $10.1016 /$ S0022-328X(97)00777-8.

16.Yamuna R, Sarath S, Kubandiran K, Umadevi M, Chakkaravarthi G. Synthesis, characterization and thermal studies of 1, 3-bis (4-pyridyl) propane bridged dicobaloximes. Journal of Organometallic Chemistry.2016 Jun ;811:40-47. DOI:10.1016/j.jorganchem.2016.03.015.

17. Wani MY, Kumar S, Arranja CT, Dias CMF, Sobral AJFN. Cycloaddition of CO 2 to epoxides using di-nuclear transition metal complexes as catalysts. New Journal of Chemistry. 2016 Mar ;40(6):49744980. DOI: 10.1039/C5NJ03198B. 
